INTER NATIONAL MONETARY FUND

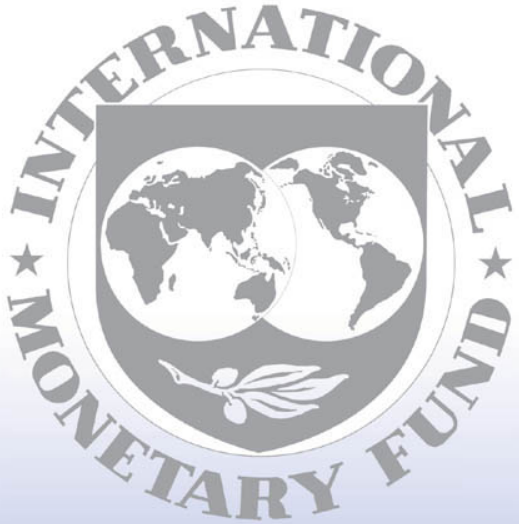

Staff

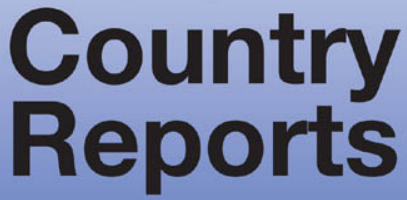




\section{Israel: Report on Observance of Standards and Codes- Fiscal Transparency Module}

This Report on the Observance of Standards and Codes on Fiscal Transparency for Israel was prepared by a staff team of the International Monetary Fund as background documentation for the periodic consultation with the member country. It is based on the information available at the time it was completed on March 30, 2004. The views expressed in this document are those of the staff team and do not necessarily reflect the views of the government of Israel or the Executive Board of the IMF.

The policy of publication of staff reports and other documents by the IMF allows for the deletion of market-sensitive information.

To assist the IMF in evaluating the publication policy, reader comments are invited and may be sent by e-mail to publicationpolicy@imf.org.

Copies of this report are available to the public from

International Monetary Fund • Publication Services

700 19th Street, N.W. • Washington, D.C. 20431

Telephone: (202) 6237430 • Telefax: (202) 6237201

E-mail: publications@imf.org • Internet: http://www.imf.org

Price: $\$ 15.00$ a copy

\section{International Monetary Fund Washington, D.C.}


INTERNATIONAL MONETARY FUND

ISRAEL

\title{
Report on the Observance of Standards and Codes (ROSC) Fiscal Transparency Module
}

\author{
Prepared by the Fiscal Affairs Department \\ Approved by Michael Deppler and Teresa Ter-Minassian
}

March 30, 2004

\section{EXECUTIVE SUMMARY}

This report provides an assessment of fiscal transparency practices in Israel in relation to the requirements of the IMF Code of Good Practices on Fiscal Transparency based on discussions with the authorities and other organizations, the authorities' response to the IMF fiscal transparency questionnaire, and other sources of information. The IMF Manual on Fiscal Transparency

(http://www.imf.org/external/np/fad/trans/manual/) should be consulted for further explanation of the terms and concepts discussed in this report.

Israel meets the requirements of the fiscal transparency code in many areas. Central government internal accounting and control functions are effective. The external audit function includes performance audits, which attract much public interest. Information on the fiscal operations of the central government in the aggregate is available monthly. Taxpayer rights and obligations are transparent. The passage of a Freedom of Information Act four years ago should foster and enhance all aspects of fiscal transparency in all its aspects. In addition, the recent decision to publish a detailed macroeconomic framework with the budget will enhance budgetary transparency.

Improvements are possible in budgetary preparation, particularly with regard to the macroeconomic underpinnings of the budget, budget execution, and expenditure classification. The budget documents should include a more systematic analysis of the impact of shocks and forecast errors on the budget. The uncertain economic environment in which the budget must be formulated and executed makes such sensitivity analyses all the more important. The budget documents should include some additional information on budget execution, including a revised projection for the year in course. They should also include information on general government and the financial statements of the larger government companies. The expenditure classification system needs to be reformed so that it conforms fully to international practice. This reform will make the budget's presentation of expenditure programs more meaningful. Finally, the availability of English versions of important laws and other relevant information might be increased.

Reports on Standards and Codes (ROSCs) are undertaken on a voluntary basis by Fund Member countries. Publication of the ROSC occurs with the member's agreement and after prior notification to the Executive Board of the IMF. 


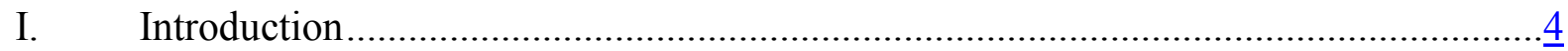

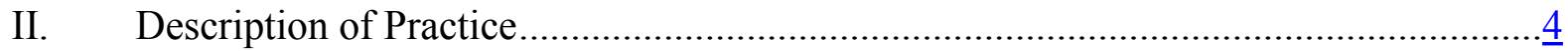

A. Clarity of Roles and Responsiblitities.........................................................

B. Public Availability of Information..............................................................

C. Open Budget Preparation, Execution, and Reporting …………………….....13

D. Assurances of Integrity .............................................................................

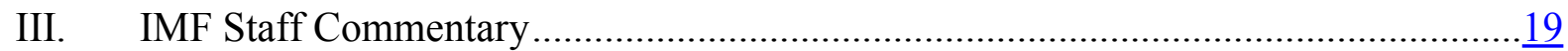

Boxes

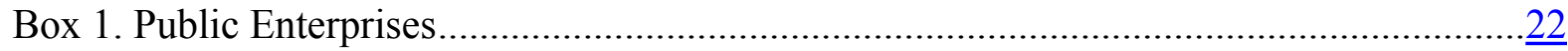

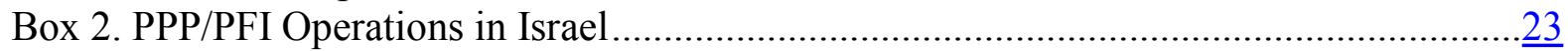

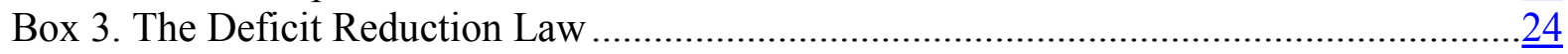

Box 4. Recording of Interest Payments on Public Debt …………….................................. 


\section{Abbreviations ANd ACRONYMS}

\begin{tabular}{|c|c|c|}
\hline $\mathrm{ABL}$ & Annual Budget Law & http://www.mof.gov.il \\
\hline AGD & Department of the Accountant General & http://www.mof.gov.il \\
\hline BLSE & Basic Law of the State Economy & \\
\hline BOI & Bank of Israel & http://www.bankisrael.gov.il \\
\hline DRL & Deficit Reduction Law & \\
\hline CBS & Central Bureau of Statistics & http://www.cbs.gov.il/ \\
\hline GCA & Government Companies Authority & \\
\hline GCL & Government Companies Law & \\
\hline EAL & Economic Arrangements Law & http://www.knesset.gov.il \\
\hline FBL & Foundations of the Budget Law & http://www.mof.gov.il \\
\hline FMIS & Fiscal Management Information System & \\
\hline GFS2001 & Government Finance Statistics Manual 2001 & \\
\hline IAU & Internal Audit Unit & \\
\hline IPO & Initial Public Offerings & \\
\hline IFTRIC & Israel Foreign Trade Risk Insurance Company & http://www.iftric.co.il/ \\
\hline MOF & Ministry of Finance & http://www.mof.gov.il \\
\hline NFPC & Non-financial Public (State-owned) Corporations & \\
\hline NII & National Insurance Institute & http://www.btl.gov.il \\
\hline PM & Prime Minister & \\
\hline PMO & Prime Minister’s Office & \\
\hline ROSC & $\begin{array}{l}\text { Reports on the Observance of Standards and } \\
\text { Codes }\end{array}$ & \\
\hline $\mathrm{SC}$ & State Comptroller & http://www.mevaker.gov.il \\
\hline $\mathrm{SCO}$ & State Comptroller's Office & \\
\hline SDDS & Special Standard Dissemination Standard & http://dsbb.imf.org \\
\hline SNA & System of National Accounts & \\
\hline
\end{tabular}

Israel: Basic Data

Type of government: Parliamentary democracy

Fiscal year: January 1 to December 31 .

Population (2003): 6,688.4 million

GDP (2003 CBS estimate ): NIS 495,360 million

Gross Public Debt/GDP (2002): 105.3\% 


\section{INTRODUCTION ${ }^{1}$}

1. This draft report provides an assessment of fiscal transparency practices in Israel against the requirements of the IMF Code of Good Practices on Fiscal Transparency. The assessment has two parts. The first part is a description of practice, prepared by the IMF staff on the basis of discussions with the authorities and their responses to the fiscal transparency questionnaire, and drawing on other available information. The second part is an IMF staff commentary on fiscal transparency in Israel.

\section{Description of Practice}

\section{A. Clarity of Roles and Responsiblitities}

\section{The coverage of general government in Israel adheres quite closely to the} recommended coverage of System of National Accounts 1993 (SNA1993). General government consists of the state, the National Insurance Institute (NII), a social security institution, a number of extra-budgetary funds, the National Institutions ${ }^{2}$, several decentralized agencies and nonprofit institutions that are largely financed by the central government, 266 local authorities, local associations and religious councils. The state consists of the Knesset (legislature), the presidency, 20 Ministries, and the State Comptroller's office. In addition, general government includes a group of health maintenance organizations (sick funds) that, because they derive more than half of their income from fees for their services, SNA1993 would not classify as part of general government.

\section{Government activities are clearly distinguished from those of public financial} institutions and nonfinancial public (state-owned) corporations (NFPCs), although the NFPC sector remains relatively large. The Government Companies Law (GCL) of 1975 provides the framework for the operation of government companies. Government companies may be either business oriented companies, which correspond to non-financial public

\footnotetext{
${ }^{1}$ Discussions on fiscal transparency were held in Jerusalem during July 6-17, 2003. The staff team, comprised of Mr. Mackenzie (head), Ms. Kester and Ms. Dabán (all FAD) and Mr. Mehrez (EU1), met with officials from the Ministry of Finance, including the departments of the accountant general, budget, debt management, state revenue administration, and research; the Ministry of Defense, the Ministry of Education, the Ministry of Justice, the State Comptroller, the Civil Service Commission, the Bank of Israel, the Central Bureau of Statistics, the Ministry of Interior, the Ministry of Housing and Construction, regulatory agencies, the Government Companies Authority, and the Finance Committee of the Knesset (the parliament). The mission also met with representatives of the private sector.

${ }^{2}$ In a reflection of the country's origins, general government also includes the operations of the Jewish National Agency and three other agencies active in the period leading up to Israel's foundation. Their present day operations are comparatively small.
} 
corporations or non-profit institutions. The GCL establishes the basic principle that government companies are to be managed according to the principle of business interest and they are subject to the same tax laws and labor statutes that apply to all companies and enterprises (private, government and mixed). A small number of government companies are required to subsidize certain goods and services. ${ }^{3}$ These subsidies are explicitly included in the State budget, and do not constitute quasi-fiscal activity. The government's holdings in the non-financial corporate sector remain substantial. The gross assets of the business oriented government companies and business mixed companies amounted to NIS 124 billion, (27 percent of GDP) at end-2001. The total number of business oriented companies in which the government has a controlling interest totaled 31 as of June 30, 2002. (see Box 1) ${ }^{4}$ The government maintains controlling holdings in two commercial banks, which, in turn, have holdings in a number of non-bank financial intermediaries. The principle of business interest applies to both the banks and the institutions in which they have an interest. The government has embarked on a number of joint ventures with the private sector in the form of BOT and PFI, including construction of a toll road now underway (see Box 2).

4. Privatization processes are generally transparent. The legal basis for privatization can be found in the GCL. ${ }^{5}$ The government companies authority (GCA), which is the government's executive agency for privatization, oversees the preparation of enterprises for privatization, and advises the government on the techniques and procedures to be followed. The GCA prepares a proposal on a public enterprise that is a potential candidate for privatization for a ministerial committee on privatization normally composed of the ministers of finance, justice, transportation, and public security and the minister in the ministry of finance. If the committee approves the proposal, it is submitted to the Knesset finance committee for its approval. The GCA has, in the past, recommended the use of initial public offerings (IPOs), and both open and closed tenders to privatize particular enterprises. The

\footnotetext{
${ }^{3}$ As an example, the state-owned water company Mekorot, which supplies around 65 percent of water consumption, receives payments from the government to compensate it for the below cost tariffs charged mainly to agricultural consumers.

${ }^{4}$ The government companies authority is responsible for supervising government companies. At end2002, the 9 largest business-oriented government companies were: El Al (the national airline), Bezeq Israel Telecommunications Corp. Ltd., Oil Refineries Ltd., Israel Aircraft Industries Ltd., Israel Electric Corp., Ltd., Mekorot Water Company, Ltd., Zim Israel Navigation Company, Ltd., Israel Military Industries (Taas) Ltd., and Petroleum and Energy Infrastructures Ltd. El Al has been partially privatized. The government's remaining holdings in El Al are to be sold by a date that depends on the date of the exercise of the options that were sold with the first share offering. The GCA issues an annual report with comprehensive information on government companies' operations with a lag of about one year. Statutory Enterprises, which are established by special legislation are not subject to the GCL except for clause No. 60, which pertains to appointments.

${ }^{5}$ Privatization encompasses the full or partial sale of the government's holdings in a government or mixed enterprise.
} 
choice of procedure is described as depending on the characteristics of the enterprise concerned and the state of domestic and international capital markets.

\section{The legal framework for the Bank of Israel (BOI) clearly demarcates its} activities from those of the government. The Bank does not engage in quasi-fiscal activity. In addition to its roles in formulating and conducting monetary policy and regulating the banking system, the $\mathrm{BOI}$ acts as the fiscal agent for the government. It does not charge for its services, or maintain a record of their cost. The BOI may extend an overdraft to the government. The outstanding overdraft must not exceed 1.6 percent of budgeted expenditure for more than two periods not exceeding 30 days each, and must never exceed 3.2 percent of annual budgeted expenditure. The BOI makes an annual transfer of its profits to the budget, unless the loss carryover from previous years exceeds the profits of the current year.

\section{Government regulation of utilities and the private sector is generally}

transparent. In the case of utilities, the regulatory approach varies somewhat from industry to industry. The electric utilities are subject to the oversight of the Public Utilities AuthorityElectricity, an independent regulatory agency, whose decisions are posted on its website. In the case of water utilities, a proposal to change rates must be endorsed by the ministers of finance and infrastructure, after consultation with the water council and then submitted to the Knesset for its approval. Gasoline and other fuel price increases must be endorsed by the ministers of finance and energy and approved by the Knesset. With respect to telecommunications, fixed line prices are established by a committee of experts appointed by the minister of communications and final decisions are to be approved by the government and the Knesset. The central bank is responsible for the regulation of banks; the ministry of finance (MOF) regulates insurance companies, mutual funds and pension funds.

\section{The legal framework establishes a clear allocation of responsibilities between} different levels of government and a stable basis for intergovernmental fiscal relations. The Basic Law of the Government, which establishes the framework of government does not determine a division of expenditure program responsibilities between the central government and the local authorities. ${ }^{6}$ Israel is a centralized state, and the central government both finances and administers many expenditure programs that in other countries would fall to the local authorities. The Municipal Ordinance Law, the Local Councils Ordinance Law and subsequent legislation authorize the Ministry of the Interior to supervise the local authorities. Any tax a local authority levies must be based on municipal law. The annual budgets of all local authorities require the approval of the ministry of the interior. Local authorities also require the permission of the central government to borrow. As a result, the central

\footnotetext{
${ }^{6}$ Israel does not have a written constitution. It has a number of basic laws that establish the basic framework of governance. The exact status of these laws, and their rank vis à vis ordinary laws, is a matter of some debate. All non-basic laws and some basic laws can be amended or annulled by a simple majority vote in the Knesset. Other basic laws can be amended or annulled only by a special majority vote in the Knesset.
} 
government exercises direct control over their budgets. ${ }^{7}$ This control effectively enables it to assign expenditure program responsibilities between the levels of government, and to apportion the tax base between the central and local governments. Amendments to the legal framework can in principle change substantially the taxing and spending roles of the different levels of government.

\section{The roles of the executive, legislative and judicial branches are clearly defined in} the law. Israel is a unicameral parliamentary democracy. The Basic Law of the Government establishes the government, composed of the prime minister and other ministers (the cabinet) as the executive authority of the State. It holds office by virtue of the confidence of the Knesset, which is the legislative branch. The Knesset has 120 members. Any new legislation or legislative amendments requires the approval of a simple majority of the Knesset to become law. The Knesset finance committee must approve changes to regulations that apply to the tax laws. The judiciary is fully independent of the legislative and executive branches. In general, the courts adhere to the principle that parliament (the Knesset) is sovereign. However, the High (Supreme) Court can overrule a clause or line item in the Annual Budget Law (ABL) if it determines that that clause or line item contradicts the Foundations of the Budget Law (FBL).

\section{The basic principles of the legal and administrative framework of fiscal} management and expenditure are clear. The Basic Law of the State Economy (BLSE) and the FBL give the government the authority to tax and spend. The BLSE stipulates that any tax, compulsory levy or other compulsory payment requires a law, or must be imposed under law. The FBL, which corresponds to a general budget law, limits the amount the government may spend in any financial year to the amount specified as expenditure in the ABL. The FBL is more detailed than the BLSE. It focuses on financial compliance, and lacks sections on such topics as the classification scheme for the budget, the macroeconomic aspects of budgeting and detailed reporting requirements. The budget balance that the ABL includes is required to conform to the deficit stipulated in the Deficit Reduction Law (DRL), which was passed in 1991 and subsequently amended a number of times. ${ }^{8}$ The ease with which the DRL may be amended has compromised the binding character of the targeted deficit. An important feature of the budget process in Israel is the joint submission with the ABL of the Economic Arrangements Law (EAL), which is effectively omnibus legislation that includes measures reflected in the appropriations of the ABL, as well as provisions for structural economic reform. ${ }^{9}$

\footnotetext{
${ }^{7}$ The FBL gives the minister of the interior, jointly with the minister of finance, the right to reduce the amount of any budgeted transfer to a local authority when the authority has exceeded its budget or staff ceiling, and has not taken adequate corrective action.

${ }^{8}$ See paragraph 30 .

${ }^{9}$ Officials of the ministry of justice, in particular the Attorney General, argue that the EAL should include only provisions that are directly linked to the budget. In addition, since this law usually also
} 
10. The ministry of finance has strong overall control of the budgetary process. The BLSE prescribes that the state budget proposal be presented to the Knesset for approval no later than sixty days prior to the start of the fiscal year. To conform to this deadline, the Budget Department of the MOF begins budgetary preparations in April, when it sends requests to line ministries for their budget proposals; the MOF generally receives proposals from line ministries by the end of July. After further consultations with ministries during August and September, and the cabinet's approval of the budget proposal, the MOF finalizes the proposal and accompanying documents and presents them to the Knesset by the end of October. The Knesset is to approve the budget by the end of December for implementation in the new budget year. There is one important exception to this process: the expenditure that is entailed by the institution of private members' bills is not subject to all the normal budgetary controls. A recently passed law requires that a private member's bill without the approval of the government and with a budgetary cost of 5 million or more NIS should receive the majority support of the Knesset with at least 50 members voting in the bill's favor. The Accountant General's Department (AGD) of the MOF is responsible for ensuring the formal compliance of budget execution with appropriations.

\section{Mechanisms for the coordination of extra-budgetary funds and activities with}

the budget are well defined. Israel has three extra-budgetary funds. The first of these is the Bi-national Research Fund, which comprises three separate research funds with the United States, Germany and China. Israel contributes to each fund. The second is the fund for government guarantee losses, which is a fund managed by the AGD to cover the losses that might result from guarantees extended by the Government of Israel to Israeli corporations and other entities. The fund is financed by premiums paid by the beneficiaries of the guarantee. The third fund is a special deposit with the Bank of Israel of the money that was raised in the 1990s with the guarantee of the U.S. government that is designated to finance private sector infrastructure development and general borrowing by the Government of Israel. The United States requires as a condition for the extension of its guarantee on sovereign borrowing that the government should meet its budget expenditures ceiling target for 2003, and should achieve declining fiscal deficits (as a percentage of GDP) in the following years, primarily through spending cuts and not tax increases.

12. Taxation has a clear basis in law. All tax laws, including those laws that would establish new taxes or modify existing ones, require for their approval a simple majority in the Knesset. Tax expenditures also require the Knesset's approval Similarly, amendments to existing legislation require legislative approval. Changes to administrative regulations, such as those that determine the rates or fees of particular taxes or levies, require the approval of the Knesset's finance committee. Any exemption from taxation requires legislation. ${ }^{10}$

includes important tax policy measures, it should be subject to the ordinary and longer discussion timetable that, as a general rule, applies to other legislation.

10 The main tax laws are: the Income Tax Ordinance (new version) 5721-1961, the Income Tax (Inflationary Adjustment Law), 5745-1985, the Land Tax Law (Betterment, sale and acquirement), (continued...) 


\section{The tax system is not unduly complicated, and its administration is taxpayer-}

friendly. The value-added tax is a simple one-rate levy. Income taxation has a schedular element, and is more complicated, although its design allows it to rely to a great extent on final withholding. Both the Customs and VAT Department and the Income Tax and Property Tax Department of the MOF maintain websites that provide assistance and information on a wide variety of taxpayer problems and questions. Each year, the income taxpayer receives a booklet that explains how the taxpayer should calculate his or her tax liability. The discretionary power of tax inspectors is strictly limited by law, and the right of appeal is well established by law.

\section{Public servants are subject to a code of behavior and other provisions that} enjoin the ethical and impartial discharge of their duties. The civil service is subject to the provisions of various statutes as well as the provisions of general laws that pertain to issues of conflict of interest and moral rectitude. ${ }^{11}$ Tax officials in particular are bound by a code of confidentiality to which only a few well-defined exceptions apply. The civil service is also subject to a number of administrative directives. ${ }^{12}$ The civil service must adhere to a code of ethics. ${ }^{13}$ Most civil service positions are filled by competition based on merit.

\section{B. Public Availability of Information}

\section{The publicly available information on the central government is comprehensive} but not detailed. ${ }^{14}$ The published budget documents include a functional and an economic classification of expenditure that is highly aggregated. Expenditure appropriations are broken down into those financed by general revenue and those financed by earmarked revenue. The classification scheme for expenditure and revenue does not fully conform to international

5723-1963, the Property Tax and Compensation Fund Law 5721-1961, Encouragement of Capital Investment Law 5719-1959, the Value Added tax on Nonprofit Organizations, Financial Institutions Law, the Tax (Collection) Ordinance, and the Employers' Tax Law 5735-1975.

11 Theses statues are: the Civil Service Appointments Law, 5719-1959; the Civil Service (Discipline) Law, 5723-1963; the Civil Service (Restriction of Political Party and Fundraising Activities Law, 5719-1959; the Public Service (Limitations after Retirement) Law, 5729-1969; and the Public Service (Gifts) Law, 5739-1979.

12 These are grouped in Sections 42 and 43 of the Civil Service Code.

${ }^{13}$ See Civil Service Commission Notice 87/81.

14 In addition to the state, budgetary central government includes the NII and the decentralized agencies. The operations of the NII and the decentralized agencies are consolidated on a net basis. Only transfers to the budget from the NII and from the NII to the budget are recorded. The surplus of the NII is recorded as non tax capital revenue of central government. The decentralized agencies covered by the central government budget comprise the government printer, government hospitals, Jaffa and Hadera ports, Postal Bank, and the Israel Lands Administration. By law, the State Comptroller's budget is determined by the Knesset finance committee and is published separately. 
standards. In particular, capital revenue includes loan proceeds, and expenditure includes debt amortization. ${ }^{15}$

\section{The published budget documentation reports an aggregate figure for defense.}

Defense expenditure is clearly identified in the budget, under a functional and administrative classification, but for national security reasons only an aggregate figure is reported.

According to the BLSE (Amendment No. 2), the details of the ministry of defense's budget are to be presented not to the Knesset but to a joint committee of the Finance Committee and the Foreign Affairs and Security Committee of the Knesset. Defense expenditure is subject to the scrutiny of the State Comptroller (SC). For reasons related to the security of the State or to foreign relations, the joint committee may decide that the SC's report, or some parts of it, shall not be published.

\section{The published budget documents include comparative figures on the previous} year's budget, realized figures for the year before that, and projections for the next two years. However, estimates for the previous year's fiscal performance (expenditures) are not included in the budget documents. The BLSE requires that the budget proposal include a three-year projected budget (i.e., disaggregated projections for revenue and expenditure), which must be consistent with the deficit targets that the DRL has established. These medium-term projections, which are not binding on subsequent budgets, do not require Knesset approval. A statement on medium-term fiscal policy objectives and the underlying macroeconomic scenario, which is not a legal requirement, is normally attached to the budget proposal. $^{16}$

18. The regular publication of data on the execution of the budget is required by law and a calendar of release dates is routinely announced. The BLSE and the FBL require the MOF to submit a report on the execution of the state budget to the Knesset no later than six months after the end of the fiscal year. This annual report, prepared by the Accountant General's Department (AGD) of the MOF, must contain information that is at least as detailed as that in the ABL, and must explain in detail the more significant transfers from one

\footnotetext{
${ }^{15}$ The budget documents submitted to the Knesset for its approval include the Blue Books and the "Major Provisions of the Budget" booklet of explanatory notes to the proposed ABL. The Blue Books show proposed aggregate amounts for each line ministry's expenditure, detailed by programs; the "Major Provisions " booklet presents a summary of the budget's main aggregates (revenue and expenditure) and a declaration of the goals of fiscal policy. The Green Books, which are printed after the Knesset approves the ABL, contain a more detailed itemization of authorized expenditures in line ministries' programs. The Knesset must approve the amounts in the Blue Books, but not the more detailed line items in the Green Books. The "Major Provisions" booklet and Blue Books are available at the MOF web page http://www.mof.gov.il both at the time they are submitted to the Knesset and after they have been passed by the Knesset.

${ }^{16}$ The 2002 budget proposal included a report containing medium-term macroeconomic projections and a sensitivity analysis (two alternative macroeconomic scenarios) for 2002-05 elaborated by the $\mathrm{BOI}$, the MOF, and the prime minister's office (PMO).
} 
line item to another. ${ }^{17}$ The FBL also establishes that the MOF should update the budgetary estimates, by incorporating the in-year adjustments the Knesset has approved and the in-year change of macroeconomic variables. The FBL provides that the MOF is to submit a quarterly report on the deficit and its financing based on cash data to the Knesset. In practice, the AGD produces both monthly and quarterly reports. These reports include not only estimates of the deficit and its financing, but also information on the execution of revenues and expenditures of the central government (although the classification scheme used deviates from international standards (see http://www.mof.gov.il). However, a complete update of the budgetary estimates of revenue and expenditure is not carried out regularly. As a rule, the estimates of the deficit and its financing are published no later than the sixth business day of the succeeding month. Israel has subscribed to the IMF's Special Data Dissemination Standard (SDDS) for economic and financial statistics. A home page for Israel, containing metadata on the statistical series published by the Central Bureau of Statistics (CBS), has been launched on the IMF web site (http://dsbb.imf.org).

\section{Comprehensive quantitative information on most of the central government's} contingent liabilities is published. According to the State Guarantees Law, the government enjoys a general authority to issue financial guarantees of third-party obligations to promote important economic sectors or other activities or purposes in the interest of the public. In practice, financial guarantees are divided into three categories: (i) guarantees to support such economic activities as capital investment, small business activity, and investment in publicly traded venture capital funds; (ii) special guarantees to support government-controlled entities, particularly in the defense sector, or other enterprises or activities on a case-by-case basis; and (iii) guarantees to support foreign trade made through Israel Foreign Trade Risk Insurance Company (IFTRIC), ${ }^{18}$ or on a case-by-case basis. ${ }^{19}$ Each guarantee program must be specifically approved in advance by the Finance Committee of the Knesset and is published in the Official Gazette. Aggregate obligations under guarantees in categories (i) and (ii) issued during each budget year may not exceed 10 percent of the total budget expenditures of the same year. The ministry of finance prepares an annual balance sheet of the financial guarantees, both realized and unrealized, that the central government has issued.

\footnotetext{
${ }^{17}$ The FBL establishes that the annual report should explain: (i) changes in appropriations above a specified threshold that are made to compensate for the impact of an increase of the consumer price index or exchange rate variations on the real value of a line item; (ii) transfers of staff positions from one budget item to another; and (iii) increases in the ceiling that applies to future spending commitments. The annual report is available on the home page of the MOF (in Hebrew).

${ }^{18}$ IFTRIC is a government-controlled company that provides medium and long-term export guarantees, and guarantees against foreign political risks on a transaction-by-transaction basis.

${ }^{19}$ For example, after the terrorist attacks of September 11, 2001, international aviation insurers gave notice of terminating war liability coverage for third-party bodily injury or property damage. In order to allow the Israeli aviation companies to continue operating, the State of Israel issued a state guarantee to INBAL Insurance Company Ltd.-a state-owned insurance company--that enables it to provide Israeli aviation companies with war liability coverage.
} 
This balance sheet is included in the annual report on Form 18-k prepared for the U.S. Security and Exchange Commission. However, information on the value of guarantees called during previous years and on the maturity profile of outstanding guarantees is not published. The financial report for the central government that the AGD prepares at year-end includes aggregate annual estimates of the outstanding stock of contingent liabilities stemming from BOT/PFI projects. No information on the maturity profile of the guarantees is provided. The annual limit on the issuance of such guarantees is clearly indicated every year in the budget proposal.

\section{Estimates of central government tax expenditures are included in the budget} documentation. As the FBL requires, estimates of tax expenditures have been included in the ABL since 1986. These estimates cover tax expenditures in the form of tax credits, tax exemptions and allowable deductions from taxable income. The State Revenue Administration includes detailed statements of the various tax expenditures and the way they are measured in its annual report . It also includes an analysis of their economic impact.

\section{The information on the rest of general government is comprehensive, but not} timely. Aggregate measures of general government activity are not an important input to the fiscal policy debate. The CBS prepares and disseminates the consolidated data on general government operations according to the following schedule:

1. In October - the first preliminary accounts (annual estimate) for the current year 2. In December - the revised preliminary accounts (annual estimate) for the current year 3. In March - updated accounts for the year ended the previous December

4. In July - revised accounts for the last two years and final accounts for earlier years The data on general government that the BOI uses in its analyses and annual reports are almost exclusively based on data from the CBS. The BOI, aside from disseminating CBS general government data, also reports its own estimated time series for the level and composition of general government revenue and expenditure. The ministry of the interior publishes consolidated data on the financial performance of the local government sector (in Hebrew).

\section{Information on financial assets and on both gross and net public debt is}

published. By law, the AGD must prepare a balance sheet showing government assets and liabilities no later than nine months after the end of the fiscal year. ${ }^{20}$ The balance sheet is available on the MOF's home page. ${ }^{21}$ Detailed information on government equity holdings in public and private enterprises and financial statements of privatization operations is included in the annual report of the GCA. The CBS publishes quarterly and annual information on the

\footnotetext{
${ }^{20}$ Liabilities include foreign and domestic loans. As regards assets, loans, deposits and other financial assets are included, but not fixed assets such as buildings.

${ }^{21}$ State Comptroller Law, 5718-1958 Consolidated version, article 12. This Balance Sheet must be ultimately audited by the State Comptroller, the external audit body.
} 
level, maturity and currency composition of gross central government debt, in line with the IMF's SDDS (see http://dsbb.imf.org). In addition, detailed data on annual central government debt are also published by the Government Debt Management Unit of the MOF. As regards general government debt, the BOI provides annual estimates of the gross and net general government debt with its level and composition, by subsectors. ${ }^{22} 23$

23. The government is launching an e-government initiative, creating virtual service counters in all public offices. The AGD, which is responsible for all information systems management in the government, is in charge of implementing the 2003-2005 Master Plan "E-Government" Initiative. The key goals of the plan are to increase the number of services on line; ${ }^{24}$ to build a central payment and tender system; and to increase the flow of information within the government units (enhancing the current intranet) and the governmental portal. The 2004 budget includes appropriations that will allow more rapid implementation of projects that will enable a wider accessibility to information and to government offices through the government's websites. This initiative is designed to enhance transparency, make the public sector more efficient, and reduce red tape.

\section{The 1999 Freedom of Information Law provides citizens with the right to} request a very broad range of information on both fiscal and other governmental operations and policies. In principle, the law places relatively few impediments in the way of citizens seeking information on government activities. Shortly after its passage, various ministries and agencies requested the government to exempt them from the law or delay its applicability. In response, several exemptions were granted, but most were subsequently rescinded. $^{25}$

\section{Open Budget Preparation, Execution, and Reporting}

\section{The budget presentation emphasizes financial compliance rather than program} performance or the macroeconomic role of fiscal policy. The budget classification does not fully conform to international norms. The major stages of budget preparation and approval follow a regular schedule, in which the MOF plays a key role (see paragraph 10).

\footnotetext{
${ }^{22}$ See Table 1.A.3.3 in Bank of Israel annual report 2002- Statistical Appendix.

${ }^{23}$ Domestic net public debt is defined as the sum of central government debt and the debt of the local authorities, less the liabilities of private sector debtors to the government. Net external public debt is defined as the government's external debt less foreign assets of the public sector.

${ }^{24}$ At present 20 administrative services, including the significant services of fines payments, license renewals and VAT payments, can be requested on-line.

${ }^{25}$ See World Report: Libraries and Intellectual Freedom in http://www.ifla.org.
} 
The deliberations of the budget proposal at the Knesset are open to the public. The ABL sets out the government's fiscal objectives and describes the macroeconomic framework that underlines the budget. The budget's treatment of these issues is relatively general, however (see also paragraph 27). The ABL includes broad functional, economic, and program classifications that are considerably less detailed that those set out in the IMF's Government Finance Statistics Manual 2001 (GFS2001). The ABL also shows budget allocations for major infrastructural projects. With respect to BOTs and PFIs, the budget documents record the full value of the obligation or the contingent liability that the government incurs toward the private sector contractor. The actual expenditures related to the project are included in appropriations in the year in which they are to be incurred. Changes in the budget's line-byline allocations, as shown in the Blue Books, need the prior approval of the Finance Committee of the Knesset. Such changes can be made only if the total allocation for the budget is not increased as a result.

\section{The budget proposal and the ABL could distinguish estimates of new policy} initiatives more clearly from ongoing operations. New policies and new commitments are shown in the "Major Provisions of the Budget" booklet of the explanatory notes to the proposed ABL. The "Composition of the Budget" section provides an explanation of current and investment expenditure programs and the economic and social benefits they will confer. "The Budgetary Framework" section contains an explanation of the government's fiscal policy objectives. Nonetheless, the costs of any new recurrent activities are not always clearly distinguished from the costs of established programs, and the quantitative budgetary impact of new policy initiatives and measures is not always clearly presented.

\section{Starting with the $\mathbf{2 0 0 4}$ budget, a comprehensive macroeconomic framework will} be published with the budget documents. The research departments of the MOF and the BOI prepare detailed macroeconomic forecasts, and the State Revenue Administration prepares detailed revenue forecasts relying on a variety of modeling and forecasting techniques. In the past, these were not routinely published. In August 2003, however, the MOF published a detailed medium-term macroeconomic framework with projections through 2010 covering real variables, prices, and labor market indicators. The macroeconomic framework and an accompanying explanatory report were prepared in the Economics and Research Department at the MOF and were widely disseminated via the MOF's internet site. The projections presented in this publication were incorporated in the assumptions used in the 2004 Budget.

\section{The overall balance of the central government, rather than the balance of the general government, is the main indicator of the fiscal position in the budget. It is monitored on a monthly basis along with revenues and expenditures. The primary} balance, the domestic balance, ${ }^{26}$ the foreign balance and the stock of outstanding debt of the

\footnotetext{
${ }^{26}$ In Israel, the domestic balance refers to the difference between domestic expenditures and revenues. The financial assistance received from the United States is included as income in the foreign balance. The foreign balance refers to the difference between foreign revenues and
} 
central government are viewed as important indicators and are tracked with the same frequency. The lag in compiling and publishing information on general government means that the general government deficit is not a particularly useful fiscal indicator. The relatively centralized character of Israeli government makes the lack of timely general government data less problematic than it might be in other countries.

\section{The application of the DRL may have reduced the transparency of the} budgetary projections. The intent of the DRL was to achieve a decline in the deficit by setting progressively smaller targets that would be binding on subsequent governments, thereby contributing to a transparent and credible medium-term fiscal policy framework. In the event, all the governments that have taken office since the DRL was enacted have amended it to change the targeted path for the deficit. In addition, because the DRL prescribes the ex-ante deficit path, it appears to have created a bias for overly optimistic revenue and growth projections when the economy was growing slowly (see Box 3 ). Optimistic revenue projections permitted the ABL's expenditure allocation to be higher than it realistically could be, given the deficit target. As a result, the budget's effectiveness as an expenditure planning tool may have been lessened.

30. To make the DRL into a more effective fiscal rule the government introduced an amendment that establishes ceilings for government expenditure in the years 20052010. The law sets an annual increase for total CPI adjusted expenditure of not more than 1 percent per year. A ceiling on the budget deficit will continue to apply in each year in the 2005-2010 period. The ceiling is fixed at 3 percent of GDP for each year.

31. The budget documents do not include substantial analysis of the sensitivity of the budget estimates to changes in economic and financial conditions and do not discuss the main fiscal vulnerabilities. The budget documents do not contain either a comprehensive discussion of fiscal vulnerability, or an analysis of the sensitivity of the deficit to shocks to the economy. In particular, the ABL does not include sensitivity analyses of the impact of changes in the rate of growth of real GDP, the rate of inflation or the exchange rate on the budget.

32. The budget documents include medium-term fiscal projections as prescribed by the DRL, and beginning with the 2004 budget these projections will be supported by a detailed medium-term macroeconomic framework. These detailed macroeconomic projections, which have a six-year horizon, will also be available during the preparatory stage of the budget process (see also paragraph 27). The medium-term fiscal projections are not informed by analyses of fiscal sustainability. In particular, there is no analysis of the sensitivity of public debt to economic and financial shocks, such as unexpectedly low primary balances, higher than projected interest rates, or exchange rate depreciation. The

expenditures. Foreign expenditures include interest payments on debt held by non-residents and revenues include military and civilian grants. 
government does undertake internal studies. In particular, the AGD has established a debt management office, which conducts research on fiscal vulnerability.

\section{The budget documents set out the government's major policy objectives, but} progress in achieving them is not always reported. The explanatory section of the budget documents sets out and describes a number of policy objectives, mainly in connection with programs for particular sectors. Progress in achieving these objectives is, however, not documented in the report on the execution of the budget. The explanatory notes sometimes report and the blue books usually report on progress - or lack of it-- in achieving objectives. The program descriptions that are introduced for information in the budget documents do not include statements on the programs' objectives, and, therefore, no reports can be prepared on their performance.

\section{The central government accounting system produces timely and accurate data.}

All government departments and agencies apply uniform accounting codes and record expenditure on a commitments basis. The AGD maintains a well-designed integrated fiscal management information system (FMIS), which is linked to its treasury accounts, which, in turn, are linked to the BOI. This integration facilitates the reconciliation of treasury accounts with government accounts held at the BOI. The FMIS system produces a complete and aggregated monthly report on central government activities. This report is published on the first day of every month. The classification system that the FMIS uses is the same as that used by the ABL, which facilitates the preparation of the final accounts of the government that are submitted to the Knesset and the State Comptroller's office. The system facilitates the timely preparation of annual balance sheets (for financial assets and liabilities only) by each of the spending agencies, and the compilation of the balance sheet of the government by the MOF. The system will also facilitate a shift to accrual accounting, as envisaged under the Economic Resources Planning (ERP) initiative, which will be implemented in three years. ${ }^{27}$

\section{Internal controls are strong, and both internal and external audits are well} developed. The FBL confers on the AGD the responsibility for financial oversight in all ministries. To oversee treasury functions, the AGD places its staff in each of the ministries. In addition, the Internal Audit Unit (IAU) of the AGD in the MOF is responsible for the internal audit of the execution of the state budget in all ministries' accounting and finance units. The IAU's work plan includes audits of large government entities every two years and smaller ones every four years. Its audit reports are sent to the Accountant General. Internal audits focus on compliance with financial, legal, and administrative requirements and regulations. External audits conducted by the State Comptroller may examine any aspect of the operations of governmental entities, including their legality, effectiveness and operational efficiency. These audits may also investigate the conduct of civil servants, to see whether it conforms to the ethical standards expected of them. The SC may, after consultation with the

\footnotetext{
${ }^{27}$ By 2007 all ministries and public entities will start publishing annual financial statements, including audited accounts and directors' statements. These will be consolidated into one government financial statement.
} 
MOF and the AGD, lay down directives for government companies and other audited entities regarding their accounting systems. The IAU's audit reports are sent to the Director General of each audited entity. The IAU also monitors the correction of irregularities found in the internal audits and in audits by the SC's office. The IAU's operations are regulated by the Civil Service Code and by the AGD's procedural directives. The practice of external audit of the government's financial accounts is well established. The State Comptroller Law requires that the minister of finance submit to the SC a comprehensive report on the execution of the State budget within six months after the end of the fiscal year, and the State balance sheet within nine months after the end of the fiscal year. The SC's annual reports on the execution of the State budget and on the State balance sheet are available in good time in hard copies and on the SC's website (http://www.mevaker.gov.il).

\section{Efforts are being made to improve the accountability of local authorities. The} government plans to improve the accountability of local authorities for the amounts they spend. Recently, the Ministry of Interior exerted its lawful authority by stipulating that in the event of an unauthorized budget expenditure by a local authority, the person directly responsible for this extra expenditure will be held accountable. Local authorities are monitored by the audit department of the Ministry of the Interior, the State Comptroller, and the director in charge of wages and labor agreements in the MOF. When the local authority does not properly manage its budget, the Ministry of the Interior appoints an "accompanied accountant" (an accountant that accompanies the local treasurer) whose signature is needed for any financial commitment or expenditure of the local authority.

\section{Procurement policy and procedures are well developed and adequately}

publicized. The rules that determine the form that procurement takes: open tender, closed tender, or solicitation, are based on objective principles. The government advertises tenders in several large-circulation Israeli newspapers and on the Israeli Government Tenders website, which is run by the Government Advertising Agency. Information on the website, however, is only available in Hebrew. The MOF also posts a list of tenders on its website in English (see also Box 2).

\section{The tax and customs administrations are given adequate legal protection from} political interference. The laws prescribe that the tax and customs administrations shall exercise their duties independently from other government bodies and that other government bodies are prohibited from interfering in their functions of tax assessment and collection. The State Civil Service Commission has the authority to review cases of improper conduct by tax and customs officials. The taxpayer may appeal a decision by the authorities to the courts, whose decision is final.

\section{Assurances of Integrity}

\section{Revenue projections in recent budgets have been based on relatively high} estimates of the elasticity of revenues with respect to their bases. This practice has made budgetary projections less reliable than they could be. The need for the projections to comply formally with the DRL's targets creates incentives to make optimistic revenue projections 
(see Paragraph 29). Together with an unpredictable economic environment, the practice has caused initial budget projections of the deficit to fall substantially short of the outturn. In order to discourage the practice, the government introduced the law described above (see paragraph 30), which will set a ceiling of 1 percent on the CPI-adjusted increase in the government's annual expenditures.

\section{The current procedure for adjusting interest payments on non-indexed debt is} causing some inconsistency in the presentation of the budget. The current procedure as regards CPI indexed bonds is to include only the accrued real interest in the central government deficit. The inflation adjustment paid at maturity goes below the line. ${ }^{28}$ As regards non-indexed bonds issued before 2001, an estimate of the accrued real interest on these bonds is included in interest payments, while in the case of more recently issued debt, the full nominal interest component is included. Apart from this inconsistency, the adjustment made to debt issued before 2001 is known but not published (see Box 4).

\section{Effective tools and procedures to assure the reconciliation and internal} consistency of fiscal data are in place. The AGD's managerial information system ensures that the approved appropriations are not exceeded and that the reconciliation of commitments, budgetary appropriations, payments and bank account transactions is effective and timely. The AGD's annual report allows for a systematic reconciliation of annual final accounts with budgetary appropriations. The AGD's report contains information only on the final budget. It does not include details by program of the original approved budget or detailed information about in-year modifications. It does include the original approved budget by ministry (and other) lines. The balance sheet that the AGD prepares permits a reconciliation of the cash deficit with the financing and changes in the government's assets and liabilities.

\section{The State Controller is responsible for external audits. He or she is independent} of the executive branch. The scope of the SC's audits is virtually unlimited (see Paragraph 35). In addition to effectiveness and efficiency, the SC's audits place great emphasis on the legality of government operations and the impartial and ethical conduct of the officials responsible for them According to the law, ${ }^{29}$ the following bodies are subject to audit by the SC: all ministries; all agencies or institutions of the state, all local governments, all government companies and their subsidiaries; all enterprises, institutions, and funds in which the state has a share; any entity that is assisted by the state; and any entity that is made subject by law to audit by the SC. The Ministers' Committee on Coordination and Administration, headed by a minister in the Prime Minister's Office, deliberates on reports issued by the SC that deal with matters of general principle or systemic problems, and makes decisions accordingly. The SC is elected by the Knesset in a secret ballot, for a single seven

\footnotetext{
${ }^{28}$ In the SDDS home page for Israel, the CBS presents a memorandum item that describes the component of nominal interest included in repayment of principal to maintain its real value.

${ }^{29}$ The Basic Law: the State Comptroller Law, 5718-1958 [Consolidated version].
} 
year period. He or she can be removed only by two-thirds majority of the Knesset. The SC is subject to regulations that strictly prohibit his involvement in any matter that might entail a conflict of interest. In carrying out his functions, the SC is responsible only to the Knesset and is not answerable to the government. The SC determines the audit program of the State Comptroller's Office (SCO), except for those extremely rare cases in which the government or the Knesset requests the SC to submit an opinion on a particular issue. The budget of the $\mathrm{SC}$ is determined by the Finance Committee of the Knesset upon the proposal of the SC, and is approved separately from the state budget. The SC has independent authority to recruit or dismiss the SCO's employees.

43. The SC bases its audits on timely and comprehensive information. No later than four months after the end of the fiscal year, all audited bodies must submit a report to the SC on their financial operations during the year. The SC may also require additional information from audited bodies such as a balance sheet at the end of the fiscal year.

44. Mechanisms are in place to ensure that audited agencies take appropriate action in response to the $\mathrm{SC}$ 's findings and recommendations. The SC submits semi-annual reports to the PM containing findings and recommendations, following the audits he has conducted during the year by February 15 and July 15 of each year. The reports are tabled in the Knesset and published after a period of ten weeks, during which the PM issues a report to the SC, which is also submitted to the Knesset. This report includes, inter alia, his observations on the SC's report as well as the audited bodies' responses to it. Each of the audited bodies is required to establish a team headed by its Director General to discuss and take decisions regarding the ways of rectifying the defects revealed and the implementation of the SC's recommendations. Within eight months from the time the SC presents the reports to the PM, the PM reports on the actions taken in response to the report's recommendations.

\section{CBS is the agency responsible for the national statistics system and uses fiscal} information for preparing the national accounts. The legal basis for public statistics is given by the Central Bureau of Statistics Ordinance (New Version), 5732, 1972. The head of the CBS, the Government Statistician, is appointed by the government, upon the proposal of the prime minister. The law provides that the CBS is to act on the basis of scientific considerations in carrying out its functions. The prime minister appoints an advisory body, the Public Council for Statistics, which is to consist of representatives of public entities, institutions of higher education and research, and experts on statistics, economics, and social studies. The Statistics Ordinance establishes tough sanctions (including imprisonment for up to three years) for CBS employees who deliberately falsify statistics or exploit unpublished information for personal gain. These sanctions have never been applied.

\section{IMF STAFF COMMENTARY}

46. Israel meets the requirements of the fiscal transparency code in many areas. Central government internal accounting and control functions are effective. The external audit function includes performance audits, and its findings arouse substantial public interest. Information on the fiscal operations of the central government, albeit in a relatively aggregate 
form, is available monthly with a short lag. The effectiveness of these functions contributes to data availability and integrity. The passage of a Freedom of Information Act four years ago can be expected to protect and improve fiscal transparency in all its aspects. Taxpayer relations are transparent.

\section{The main area where further improvements are possible is budgetary} preparation and specifically the macroeconomic underpinnings of the budget. The recent decision to publish a detailed macroeconomic framework with the budget documents will enhance budgetary transparency. A more elaborate macroeconomic framework might not have eliminated the apparent upward bias to the revenue forecast that the DRL may have entailed in periods of slow growth. However, if the government is obliged to present the Knesset with a fully articulated framework, which would also be presented to the cabinet for its internal deliberations during the budgetary preparation period, any bias that exists might be more apparent. The introduction of a conservative legal limit on expenditure (see paragraph 30) should also reduce any optimistic bias in revenue projections.

48. Additional steps can be taken to enhance budgetary transparency, including the introduction of sensitivity analyses in the budget documents. The budget documents should include a more systematic analysis of the impact of shocks and forecast errors on the budget. Revenue forecasting could be made more transparent by including an analysis of the impact of revisions to the budget's assumptions about revenue in the second half of the prebudget year, and income and prices in the budget year. The uncertain economic environment in which the budget must be formulated and executed makes such sensitivity analyses all the more important. Consideration might also be given to increasing the Knesset's statutory review period from sixty to perhaps ninety days. The sixty day period might be somewhat tight for the review and debate of the Economic Arrangements Law and the Annual Budget Law concurrently. These further steps to improve the macroeconomic aspects of budgeting deserve a very high priority.

49. The budget documents should include some additional information on budget execution. The budget should include a revised projection for the year in course. It would also be helpful to include information on general government and the financial statements of the larger government companies. The legal basis for this increased information should be secured by amending the FBL as appropriate.

50. The presentation of the budget documents could be both more user-friendly, and more useful from the point of view of assessing the effectiveness and efficiency of the government's expenditure programs. Specifically, the expenditure classification system needs to be reformed so that it conforms fully to international practice. This reform will make the budget document's presentation of expenditure programs more meaningful. Given the government's sophisticated accounting systems, this reform should not be technically challenging, especially in view of the fact that the Economic Resources Planning (ERP) initiative is already in place. 
51. The availability of English versions of important laws and other relevant information might be enhanced. An impressive amount of information is available on government websites regarding government operations and activities. Naturally, most of it is in Hebrew. However, some important information, including some important laws that are useful to international investors and Israeli economy watchers could be translated into English. Some of this material has been translated into English by law firms and other firms doing business in Israel, but it is not generally available. 


\section{Box 1. Public Enterprises}

Between 1986 and 2002, the Israeli government has privatized 83 enterprises with a market value exceeding US $\$ 8$ billion. Bank privatizations accounted for 70 percent of this total. In 2002, there remained 103 public enterprises of which 46 were business oriented. These enterprises, which do not include mixed public/private enterprises, accounted for 3 percent of GDP, 1.6 percent of total employees, and 7.6 percent of total exports.

Public enterprises are concentrated and prominent in several sectors-electricity, water, communication, transport, and defense (see Table 1). Of the fifty-two thousand employees in business oriented public enterprises, close to 90 percent are employed in eight large enterprises (see Table 2). In addition, the government holds controlling shares in two major banks - Bank Leumi, and Bank Discount, and has control over the Port Authority, which employs close to four thousand people. There are no public enterprises in the non-defense goods-producing sectors.

Table 1. Employees in Public Enterprises by Sector, 2001

(In thousands)

\begin{tabular}{lr}
\hline & \\
Defense industries & 18.6 \\
Electricity and water & 15.8 \\
Transportation and communication & 15.0 \\
Energy & 1.6 \\
Construction, tourism, and services & 0.4 \\
Agriculture & 0.4 \\
Manufacturing and commerce & 0.3 \\
\hline
\end{tabular}

Table 2. Main Public Enterprises: Various Indicators

\begin{tabular}{|c|c|c|c|c|c|}
\hline & Employees 4/ & \multicolumn{3}{|c|}{ In millions of dollars } & $\begin{array}{c}\text { Gov`t Share 4/ } \\
\text { (in percent) }\end{array}$ \\
\hline El Al Israel Airline 2/ & 3,249 & 1,111 & -85 & 1,819 & 99.9 \\
\hline Bezeq the Israel Telecommunication Corp. & 9,041 & 1,846 & 27 & 2,259 & 54.6 \\
\hline Oil refineries & 1,162 & 2,537 & -5 & 840 & 74.0 \\
\hline Israel Aircraft Industries & 12,168 & 2,089 & 101 & 1,474 & 100.0 \\
\hline The Israel Electric Corp. & 13,377 & 2,373 & -12 & 9,399 & 99.8 \\
\hline Mekorot Water Corp. & 2,134 & 449 & 1 & 877 & 69.0 \\
\hline Zim Israel Navigation Company 3 / & 1,195 & 1,671 & 13 & 1,067 & 48.0 \\
\hline Israel Military Industries & 3,407 & 435 & -19 & 834 & 100.0 \\
\hline
\end{tabular}

1/ In 2001.

2/ Partially privatized.

3/ Privatized in 2003.

4/ At end-2001. 


\section{Box 2. PFI/BOT Operations in Israel}

The basic goals of private financial initiative (PFI) and build-operate-transfer (BOT) operations in Israel are promoting infrastructural projects and increasing their efficiency. In recent years, about 70 percent of $\mathrm{PFI} / \mathrm{BOT}$ projects have been in transportation, with the remaining 30 percent split between water, energy and housing. The concession period of projects ranges from 20 to 35 years. The number of new projects rose from a rate of one per year in 1998 to six per year in 2002, and dropped back to one per year in 2003.

\begin{tabular}{lcccccccccc}
\hline Year & 1994 & 1995 & 1996 & 1997 & 1998 & 1999 & 2000 & 2001 & 2002 & 2003 \\
\hline $\begin{array}{l}\text { Number of } \\
\text { projects }\end{array}$ & 1 & 1 & $\ldots$ & 1 & 1 & 2 & 2 & 4 & 6 & 1 \\
\hline
\end{tabular}

Before a project is considered as a candidate for a PFI/BOT operation, it must gain the recognition of the relevant ministry and the budget department in the M.O.F. In the case of an economic project (a project with a financial return) an economic feasibility study must give it a satisfactory rating. Projects that pass this test are then assessed to determine whether they are suitable for the PFI method. To be selected, a project must satisfy a list of conditions. Inter alia, these include: the private sector, not the public sector, should bear most of the risks associated with the project; it should involve a significant operations and maintenance component; it should be complex, both technically and logistically; the public sector should not have much experience (or much successful experience) in the area; it should be possible to charge for the project's services in a way that can be used to measure the quality of the services; and there should be an adequate number of potential private sector enterprises competing for the project.

The open tender process, from the prequalification stage to the signing of the contract with the successful bidder typically takes $1 \frac{1 / 2}{2}$ to 2 years, if there are no external obstacles, As part of an effort to ensure a transparent process, the initial notice is published in English and Hebrew language newspapers and embassy officials abroad are briefed. All communications from the tender committee to bidders and participants are in writing and dispatched at the same time. All tender materials apart from those with trade secrets are available for inspection. The tender committee includes representatives of the ministry of finance and the ministry having oversight or regulatory responsibility for the project. Once the successful applicant is named, a ministerial "implementing authority" is established as a "One Stop Shop", consisting of representatives of the MOF, the relevant ministry and sometimes the relevant local authority. Sometimes the "ministerial implementing authority" is a governmental company.

The budgetary impact of a project is estimated in the course of the tendering process. If the budget for the state's contribution to the project is not approved, the state cancels the agreement, and pays a predetermined compensation to the successful bidder. The budget documents include an estimate of the cost to the government of the full commitment entailed by a PFI operation. For example, in the case of one project in housing, a private contractor built apartments for elderly persons and leased the units to the government for a period of 15 years. The government recorded the current annual payment in the budget estimates, but included an estimate of the obligation it will incur over the life of the commitment in the estimate of its liabilities. 


\section{Box 3. The Deficit Reduction Law}

The Deficit Reduction Law (DRL) was first enacted in 1991, when the government decided to set a declining path for the budget deficit, after several years of increasing deficits and against the backdrop of the first intifada and the influx of immigrants. The incorporation of medium-term fiscal targets in a law was intended to compensate for the lack of an external anchor for fiscal policy. The adoption of the DRL would make its targets binding on subsequent governments, thereby making the medium-term goals of fiscal policy more transparent and credible.

Following the DRL's enactment, successive governments amended the law to change the year-to-year deficit targets and their trajectory. In part, this reflected the impact of substantial fluctuations in economic growth on the budget deficit. Since the DRL's target was not adjusted for the cycle, it was harder to achieve when the Israeli economy was in recession than it was in periods of robust growth. Notably, the budget overshot its deficit target in the mid-1990s, over performed in 2000, and overshot the target again in 2001 and 2003 (see Table 1). The June 2002 amendment to the law relaxed the target to make it less difficult to achieve in a period of declining economic activity.

Table 1. Israel : Central Government: DRL Ceiling Versus Actual Deficits

\begin{tabular}{|c|c|c|c|c|c|c|c|c|c|c|c|c|c|c|c|c|c|}
\hline \multirow[b]{2}{*}{$\begin{array}{l}\text { Deficit Targets by } \\
\text { year announced }\end{array}$} & 1992 & 1993 & 1994 & 1995 & 1996 & 1997 & 1998 & 1999 & 2000 & 2001 & 2002 & 2003 & 2004 & 2005 & 2006 & 2007 & 2008 \\
\hline & & & & & & & & & & & & & & & & & \\
\hline 1991 & 6.2 & 3.2 & 2.2 & 0 & & & & & & & & & & & & & \\
\hline $1994 / 1$ & & & 3 & 2.8 & $\underline{2.5}$ & $\downarrow$ & $\downarrow$ & & & & & & & & & & \\
\hline 1997 & & & & & & 2.8 & 2.4 & 2 & 1.75 & 1.5 & & & & & & & \\
\hline $2000 / 2$ & & & & & & & & & 2.5 & $\underline{1.75}$ & $\downarrow$ & 1.5 & & & & & \\
\hline February, 2002 & & & & & & & & & & & 3 & 2 & 1.5 & 1 & & & \\
\hline June, 2002 & & & & & & & & & & & & $3-3.5$ & $2.5-3$ & $2-2.5$ & $1.5-2$ & $1-1.5$ & \\
\hline $2004 / 3$ & & & & & & & & & & & & & $2.5-4$ & up to 3 & up to 3 & up to 3 & up to 3 \\
\hline & & & & & & & & & & & & & & & & & \\
\hline Actual Deficits & 3.8 & 2.4 & 2.3 & 4.0 & 3.7 & 2.7 & 2.3 & 2.4 & 0.7 & 4.4 & 3.8 & 5.6 & & & & & \\
\hline
\end{tabular}

Source: Ministry of Finance.(http://www.mof.gov.il) and Bank of Israel

1/ No specific deficit targets were given for the years 1995-1997. The only requirement was that the deficit, as percent of GDP, would decrease compared to its level in the previous year. Numbers underlined represent the deficit targets that the government decided on when it presented the budget for this year.

2/ No specific deficit targets were given for the years 2001-02. The only requirement was that the deficit, as percent of GDP, would

decrease by 0.25 percentage points compared to the previous year, and that the deficit in 2003 would be up to 1.5 percent of GDP.

Numbers underlined represent the deficit targets that the government decided on when it presented the budget for this year.

3/ The DRL was amended to include ceilings on expenditures growth between 2005-10. Accordingly, budget expenditure, indexed to the CPI,

would not increase by more than 1 percent each year and the budget deficit would not exceed 3 percent of GDP. 


\section{Box 4. Recording of Interest Payments on Public Debt}

Israel's domestic public debt ( end 2002 ) consists of bonds indexed to the CPI (about 72 percent of the total by face value), bonds indexed to the U.S. dollar (4 percent) and unindexed fixed interest bonds ( 24 percent). Of the debt service payments on CPI indexed bonds, only the real interest component is recorded as interest expenditures in the budget.

The treatment of nominal debt depends on when it was issued. In the case of debt issued before 2001 only the real component of the interest payment is recorded above the line. The real component is calculated by deducting from total interest payments an amount equal to the inflation rate during the payment period times the outstanding value of the bond. The resulting difference is recorded as debt amortization. This correction for inflation has at times been substantial. In 1999, for example, a year with relatively high inflation, the correction amounted to about $1 / 2$ percent of GDP (see Table). Since 2001, Israel has stopped making this correction on newly issued debt. Nominal interest payments on bonds issued since that date are recorded entirely above the line. With the gradual elimination of the outstanding stock of debt issued before 2001, all interest payments on un-indexed debt will be recorded above the line.

Correction to Interest Payments on Nominal Bonds (In millions of NIS unless otherwise indicated)

\begin{tabular}{ccccccc}
\hline & \multicolumn{9}{c}{ Debt } & \multicolumn{2}{c}{$\begin{array}{c}\text { Correction } \\
\text { to Nominal } \\
\text { Interest } \\
\text { Year }\end{array}$} & $\begin{array}{c}\text { CPI- } \\
\text { Indexed }\end{array}$ & $\begin{array}{c}\text { Dollar- } \\
\text { Indexed }\end{array}$ & Un-Indexed & Total & $\begin{array}{c}\text { Share in } \\
\text { GDP } \\
\text { (In percent) }\end{array}$ \\
\hline 2002 & 266,756 & 15,369 & 90,764 & 372,889 & 1,658 & 0.3 \\
2001 & 242,662 & 15,736 & 68,276 & 326,674 & 706 & 0.1 \\
2000 & 241,714 & 17,380 & 46,853 & 305,947 & 606 & 0.1 \\
1999 & 250,056 & 20,673 & 37,492 & 308,221 & 2,110 & 0.5 \\
1998 & 245,694 & 18,254 & 31,067 & 295,015 & 1,241 & 0.3 \\
1997 & 230,376 & 11,099 & 26,235 & 267,710 & 1,865 & 0.5 \\
1996 & 210,512 & 12,435 & 23,229 & 246,176 & 1,409 & 0.5 \\
\hline
\end{tabular}

